\title{
Histological Study of the Effect of Some Irrigating Solutions on Bacterial Endotoxin in Dogs
}

\author{
Léa Assed Bezerra da SILVA ${ }^{1}$ \\ Mario Roberto LEONARDO² \\ Sada ASSED ${ }^{1}$ \\ Mário TANOMARU FILHO² \\ ${ }^{1}$ Department of Clinical Pediatrics, School of Dentistry of Ribeirão Preto, USP, Ribeirão Preto, SP, Brazil \\ ${ }^{2}$ Department of Endodontics, School of Dentistry of Araraquara, UNESP, Araraquara, SP, Brazil
}

\begin{abstract}
The aim of this study was to evaluate, histopathologically, the effectiveness of mechanical preparation of root canals using different irrigating solutions in dog teeth filled with LPS after pulpectomy. A total of 120 root canals of 6 mongrel dogs were filled with a solution of LPS after pulpectomy. The irrigating solutions used were saline, 1, 2.5, and 5\% sodium hypochlorite, and 2\% chlorhexidine. No irrigation was used in the control group. The animals were sacrificed after 60 days and the teeth were fixed and demineralized. Subsequently, serial 6- $\mu \mathrm{m}$ sections were stained with hematoxylin and eosin and Mallory's trichrome for histopathological analysis and Brown-Brenn for verification of bacterial contamination. Analysis showed that the inflammatory infiltrate was statistically less intense in the groups in which the root canals were irrigated with 5\% sodium hypochlorite and $2 \%$ chlorhexidine. However, none of the irrigating solutions completely inactivated the harmful effects of LPS. Mechanical preparation associated with different irrigating solutions did not completely inactivate LPS.
\end{abstract}

Key Words: endotoxin, root canal therapy, irrigating solution.

\section{INTRODUCTION}

Endodontic microbiota $(1,2)$ and their byproducts (3) are responsible for the accumulation of inflammatory and immunologic cells in the periapical region(1), as well as for biochemical changes, such as changes in $\mathrm{pH}$ (4), the presence of immunoglobulins (5), metabolites of arachdonic acid (1), enzymes (6) and peptides with inflammatory properties, such as cytokines (1). These biological events contribute to bone and cementum-dentin resorption at the apical and periapical level (2).

Not only do Gram-negative microorganisms have different virulence and form products and byproducts that are toxic to apical and periapical tissues, but they also release endotoxin from their cell walls that can begin or enhance inflammatory response and bone resorption in these tissues.

Currently, the objective of treatment of root canals of both deciduous and permanent teeth with pulp necrosis and chronic periapical lesions is not only the elimination of bacteria, but also the inactivation of endotoxins, especially the inactivation of lipid A that is the most damaging part of endotoxins. This is not accomplished when intracanal dressings that only kill residual bacteria are used after mechanical preparation. According to Dwyer and Torabinejad (7), substances that are highly alkaline, such as $\mathrm{NaOH}$, detoxify LPS. However, these substances are considered highly aggressive to the periapical tissues.

Research has shown that irrigation with antiseptic solutions is fundamental for the cleaning of root canals (8). However, this is temporary and limited because, even at high concentrations, sodium hypochlorite does not neutralize a large number of endotoxins (9). Even if sodium hypochlorite eliminated all of the microbiota in the main root canal, it does not act effectively in the entire extension of the dentin tubules, even when associated with chelating or tensoactive substances (10) or other antibacterial agents such as chlorhexidine or hydrogen peroxide (11).

Thus, the objective of this study was to evaluate, 
histopathologically, the effectiveness of mechanical preparation of root canals using different irrigating solutions in dog teeth filled with LPS after pulpectomy.

\section{MATERIAL AND METHODS}

The $2^{\text {nd }}, 3^{\text {rd }}$ and $4^{\text {th }}$ mandibular premolars and the $2^{\text {nd }}$ and $3^{\text {rd }}$ maxillary premolars of six mongrel dogs (age: 12-18 months) of both sexes were selected for study, obtaining a total of 120 roots that were divided into 6 groups of 20 roots each.

The animals were anesthetized intravenously with $3 \%$ sodium thiopental $(30 \mathrm{mg} / \mathrm{kg}$ body weight; Abbott do Brasil Ltda., São Paulo, SP, Brazil). Standard periapical radiographs were taken before treatment and 30 and 60 days after treatment. After isolation of the dental area with a rubber dam and disinfection with $2 \%$ digluconate chlorhexidine, crown access was made with spherical diamond points (Dentsply Maillefer, Ballaigues, Switzerland). The working length was determined to $2 \mathrm{~mm}$ short of the radiographic apex using $\mathrm{K}$-files. The pulp was removed and the root canal was irrigated with $3.6 \mathrm{~mL}$ saline at each instrument change. The apical foramen was enlarged with K-files (\#20, 25 and 30, Maillefer) to the radiographic apex. Mechanical preparation was performed with K-files to the working length up to file \#40. Irrigation with $3.6 \mathrm{~mL}$ saline and aspiration were done after each instrument change. A \#30 K-file was used at the total length of the root to remove dentin chips and residue from the apical foramen.

The root canals were then aspirated and dried with sterile paper points and subsequently filled with EDTA for 3 min with agitation. After washing with 3.6 $\mathrm{mL}$ saline, the root canals were again dried and subsequently filled with a solution of LPS and saline, according to the method used previously by the authors (12). Briefly, under laminar air flow, $100 \mathrm{mg}$ Escherichia coli endotoxin (Lipopolysaccharide B E. coli 055:B5; 9.20\% Lipid A; Difco-Bacto, Detroit, MI) was suspended in $10 \mathrm{~mL}$ saline and $5 \mathrm{~mL}$ aliquots were kept at $-70^{\circ} \mathrm{C}$ until use. Coronal openings were then sealed with zinc oxide/eugenol cement (Dentsply Ind. Com. Ltda., Petrópolis, RJ, Brazil) over a sterile cotton pellet placed in the pulp chamber.

No control group without LPS was used in the present study because Silva et al. (12) have already reported that surgical trauma causes only slight to absent inflammatory reaction after 30 days.

After 10 days, the animals were again anesthetized and the teeth were isolated as described previously and the temporary seal was removed. The 120 root canals were divided into 6 groups of 20 canals each and irrigated with $3.6 \mathrm{~mL}$ of the following solutions: group I = no irrigation, LPS remained in canal; group II $=$ saline; group III $=1 \%$ sodium hypochlorite; group IV $=2.5 \%$ sodium hypochlorite; group $\mathrm{V}=5 \%$ sodium hypochlorite; group VI $=2 \%$ digluconate chlorhexidine. All irrigating solutions were obtained from the Faculty of Pharmacy, USP, Ribeirão Preto, SP, Brazil.

Mechanical preparation of the root canals was completed with \#45 to $70 \mathrm{~K}$-files to the working length using $3.6 \mathrm{~mL}$ of the respective solution of each group for irrigation and then the crown access was filled with silver amalgam over a glass ionomer cement base. All variables were tested in the same animal and in the different quadrants.

After 60 days, the teeth were again radiographed, the animals were killed with an anesthetic overdose, and mandibles and maxillas were removed. The maxillas and mandibles were dissected and sectioned to obtain individual roots. These specimens were washed and demineralized with buffered EDTA in a microwave oven (Sharp Carousel, São Paulo, SP, Brazil). The specimens were then washed in running water for $24 \mathrm{~h}$, dehydrated in increasing concentrations of ethyl alcohol, cleared in xylol and embedded in paraffin blocks. Serial $6-\mu \mathrm{m}$ sections were stained with hematoxylin and eosin and with Mallory's trichrome for histopathological analysis. Brown-Brenn stain, used for differential staining of Gram-positive and Gramnegative bacteria, showed that there was no contamination in any experimental group.

The following parameters were evaluated and the subjective qualiquantitative results were graded according to a numerical scale: a) intensity of inflammatory infiltrate: grade 1, mild; grade 2, moderate; grade 3 , severe; b) inflammatory infiltrate: grade 1 , acute; grade 2, chronic; c) thickness of the periodontal ligament: grade 1, normal or slightly increased; grade 2, moderately increased; grade 3 , severely increased; d) cementum resorption: grade 1, absent; grade 2, present; e) dentin resorption: grade 1, absent; grade 2, present; f) bone resportion: grade 1, absent; grade 2, present. The analysis was performed by one examiner only who was blinded as to the group being evaluated. All parameters 
were evaluated in all sections and the score of each root was that which occurred with the greatest frequency in the greatest number of sections. The results were analyzed statistically by the Mann-Whitney nonparametric test.

\section{RESULTS}

\section{Group I: LPS}

There were severe changes in the apical and periapical regions in the group filled with LPS with no irrigation. At the apical third, the cementum lacunas were enlarged and were empty or filled with necrotic tissue. There was also bleeding and inflammatory cells. The interstitial tissue invaginating from the periodontium had fiber dissociation, bleeding and severe mononuclear inflammatory infiltrate composed of mostly mononuclear cells and neutrophils. This was also seen adjacent to the foramen. There was cementum resorption next to the foramen in almost all specimens. The periodontal ligament had concentrated inflammatory cells both adjacent to and at a distance from the apical foramen. There were collagen fibers parallel to the

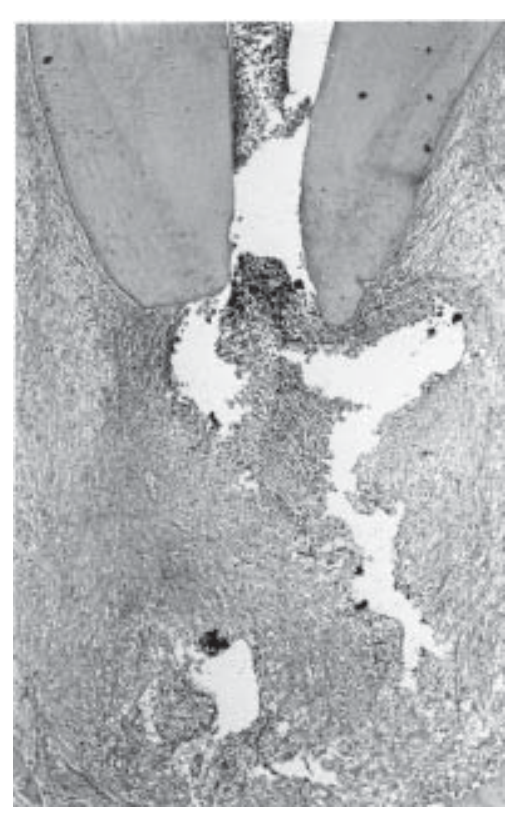

Figure 1. Group I. Histological findings showing the periodontal ligament with severe mixed inflammatory infiltrate that was more concentrated adjacent to the apical foramen. (hematoxylin and eosin: original magnification X40). apical surface next to the alveolar bone circumscribing the inflammatory process and active alveolar bone resportion with frequent osteoclasts (Figures 1 and 2).

\section{Group II: Saline}

A total of 19 of 20 roots were evaluated in this group due to the loss of one root during histological processing. Changes in the apical and periapical regions were severe in all parameters evaluated. There was a large amount of dense interstitial tissue, generalized edema and tissue necrosis in the apical region. There was active resorption of the cementum in 17 of 19 roots, and absence of fibers and cementoblasts. In the periodontal ligament, inflammatory infiltrate was intense and predominantly mononuclear in 17 roots and moderate in 2 roots $(\mathrm{p}<0.05)$. This was more concentrated at the foramen and with a considerable amount of neutrophils. There were macrophages and intense vascular proliferation and congestion at a distance from the apical foramen, with edema and a lack of collagen fibers circumscribing the inflammatory process. There were many osteoclasts in the alveolar bone indicating active resorption (Figures 3 and 4).

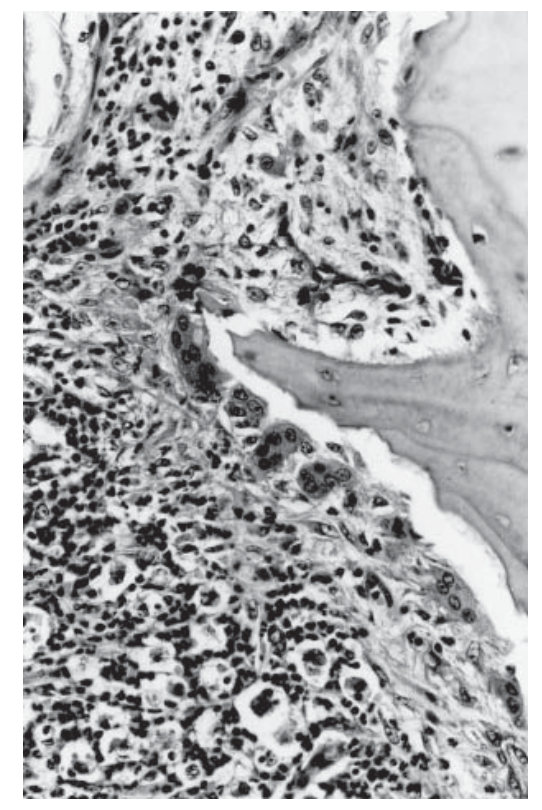

Figure 2. Group I. Alveolar bone with osteoclasts and no osteoblasts on its surface. (hematoxylin and eosin: original magnification X100). 


\section{Group III: 1\% Sodium Hypochlorite}

Only 19 roots were evaluated in this group because one was fractured during processing. There were severe changes of the apical and periapical region similar to those of the LPS and saline groups. The mixed inflammatory infiltrate was more concentrated at the foramen with a considerable amount of neutrophils and was severe in 12 roots and moderate in 6. There was diffuse inflammatory infiltrate in the periapical region and in several roots, one or more sites were adjacent to the foramen. Cementum and bone resorption was observed in 18 of 19 roots, respectively, with a large number of osteoclasts at the alveolar bone indicating active resorption (Figure 5).

\section{Group IV: 2.5\% Sodium Hypochlorite}

The apical and periapical changes were similar to those of groups LPS, saline and 1\% sodium hypochlorite with moderate/severe inflammation, cementum resorption, active bone resorption, areas of necrosis, intense vascular proliferation and congestion and a considerable number of osteoclasts and no osteoblasts (Figure 6).

\section{Group V: 5\% Sodium Hypochlorite}

In the 20 roots irrigated with $5 \%$ sodium hypochlorite, there were predominantly moderate and diffuse inflamatory infiltrate at the periapex, with some neutrophils, edema and extensive bleeding in the interstitial tissue. There were areas of resorption of cementum and an absence of cementoblasts in 9 of 19 roots $(p<0.05)$. At a distance from the foramen, there were mononuclear inflammatory cells circumscribed by fibers and a discrete presence of collagen matrix. Active resorption of the alveolar bone was present in 17 of 20 roots with a large quantity of osteoclasts and an absence of osteoblasts (Figure 7).

\section{Group VI: 2\% Chlorhexidine}

In the 20 canals irrigated with $2 \%$ chlorhexidine, the large lacunas in the apical cementum were empty or filled with inflammatory cells. The surface of the cementum was irregular due to resorption. There were

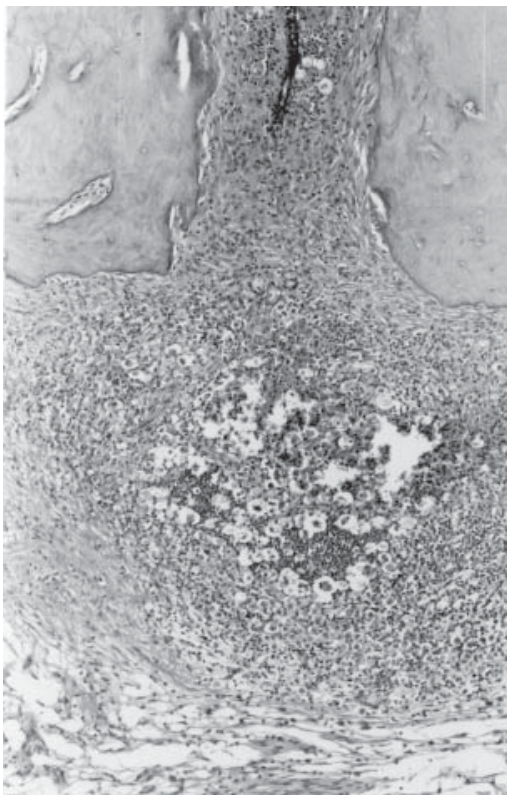

Figure 3. Group II. Root apex with cementum resorption. There is severe and concentrated inflammatory infiltrate, edema and bleeding. (hematoxylin and eosin: original magnification X40).

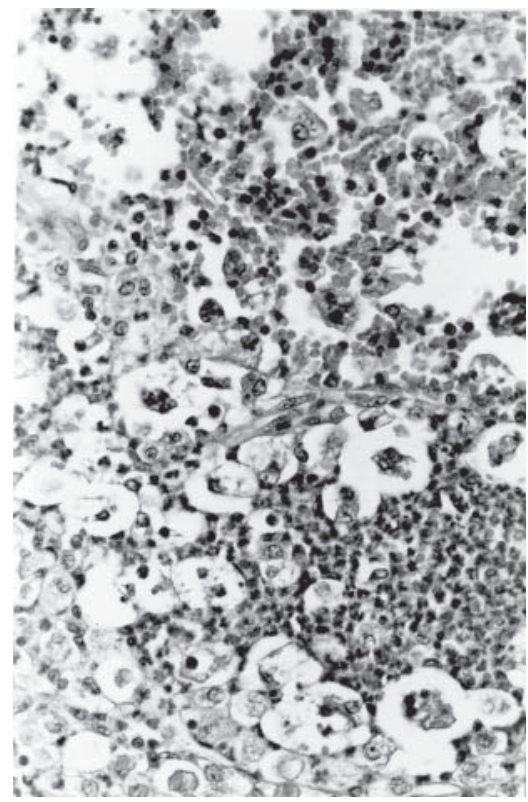

Figure 4. Group II. Detail of Figure 3 showing areas of necrosis, severe inflammatory infiltrate, fibril dissociation and bleeding. (hematoxylin and eosin: original magnification X100).

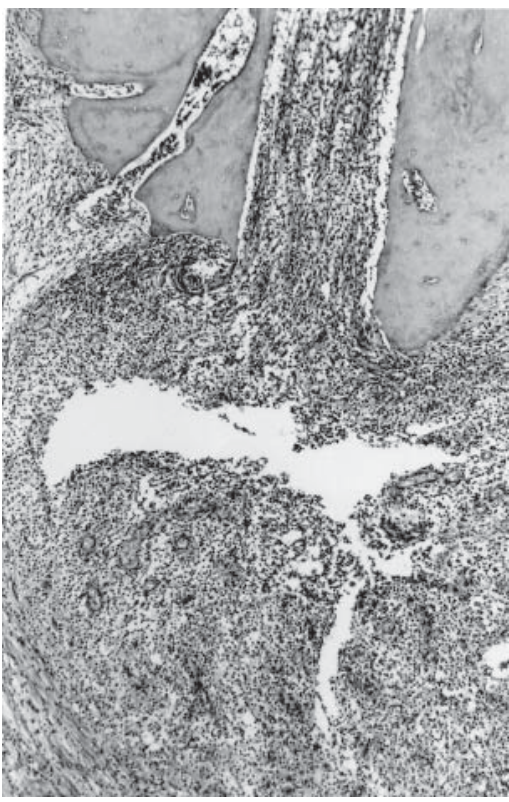

Figure 5. Group III. Cementum resorption with a severely increased periodontal ligament containing mixed diffuse inflammatory infiltrate. Collagen fibers irregularly surround the inflammatory process. (hematoxylin and eosin: original magnification X40). 
areas of necrosis and many mononuclear inflammatory cells in the interstitial tissue with tissue necrosis and fiber dissociation. There was moderate mixed inflammatory infiltrate adjacent to the apical foramen in 10 of 20 roots, intense infiltrate in 5 roots and mild infiltrate in 5 roots. Intense vascular proliferation and congestion and generalized edema were also observed. At a distance from the apical foramen, the inflammatory infiltrate was mixed with a predominance of macrophages and a discrete presence of collagen fibers circumscribing the inflammatory process. The alveolar bone frequently had osteoclasts on its surface and there were no osteoblasts (Figure 8).

\section{Statistical Analysis}

The results of statistical analysis by the MannWhitney nonparametric test showed that none of the solutions used for irrigation of the root canals with pulp necrosis and a chronic periapical lesion inactivated the bacterial LPS. There was no statistical difference in dentin, cementum or bone resorption, or thickness of the periodontal ligament among the groups. However, there was significantly less inflammatory infiltrate in both the $5 \%$ sodium hypochlorite group and the $2 \%$ chlorhexidine group than in the other groups $(p<0.05)$.

\section{DISCUSSION}

It is well known that the predominant microorganisms in root canals with pulp necrosis and a chronic radiographically visible periapical lesion are anaerobic (13), especially Gram-negative (14). These Gram-negative microorganisms release endotoxins (LPS) from their cell walls during bacterial multiplication or death, causing a series of important biological effects that lead to an inflammatory reaction and periapical bone resorption. Thus, root canal treatment of teeth with a periapical lesion must not only eliminate bacteria, but also must inactivate LPS.

During mechanical preparation, irrigating solutions must be selected to control infection of the root canal and if there is a periapical lesion, the ideal irrigating solution must detoxify LPS as well as be biocompatible and have antibacterial activity.

Despite the fact that sodium hypochlorite and

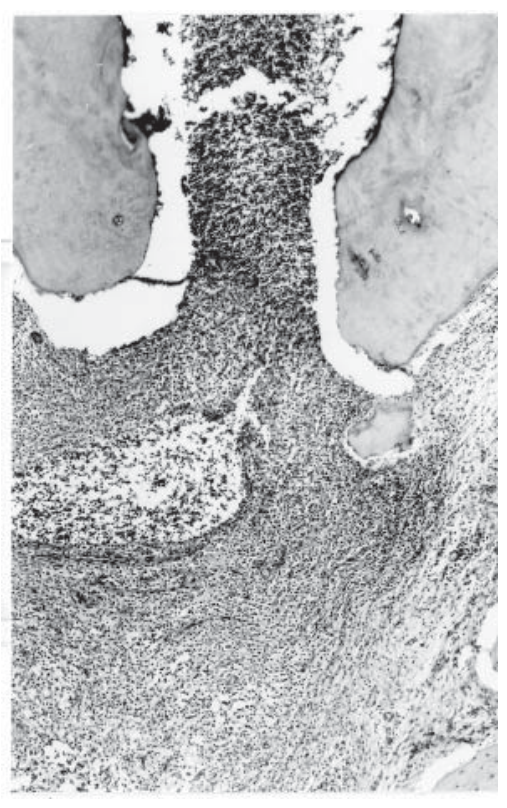

Figure 6. Group IV. Areas of resorption of apical cementum at the foramen with severe inflammatory infiltrate, edema and vascular congestion and proliferation. (hematoxylin and eosin: original magnification $\mathrm{X} 40$ ).

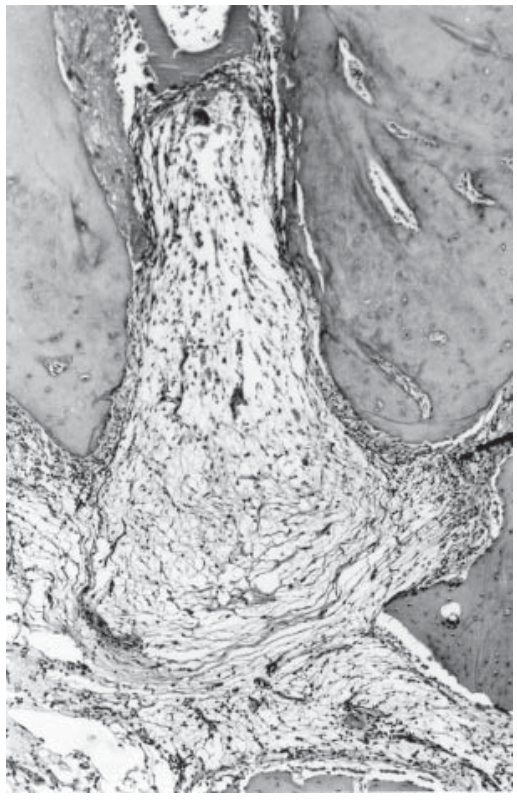

Figure 7. Group V. Apical region with moderate predominantly mononuclear inflammatory infiltrate. There were fewer inflammatory cells at a distance from the apical foramen with a discrete presence of matrix and collagen fibers. (hematoxylin and eosin: original magnification X40).

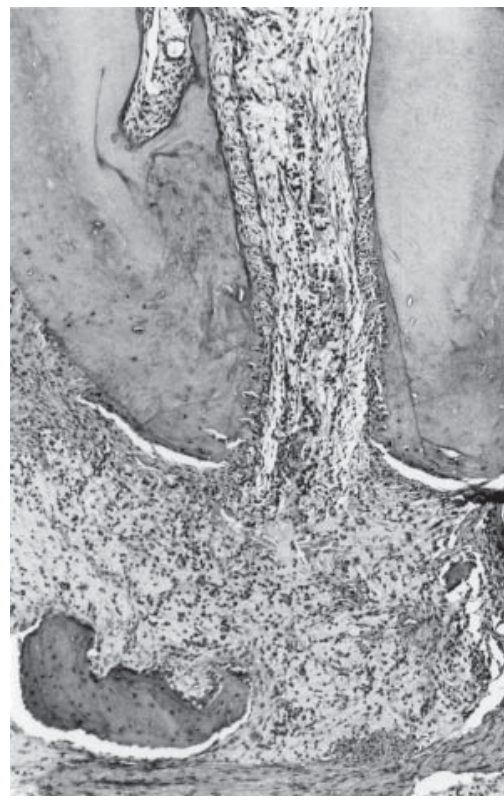

Figure 8. Group VI. Interstitial tissue at the apical and periapical region with moderate inflammatory infiltrate and moderate vascular proliferation. (hematoxylin and eosin: original magnification X40). 
chlorhexidine have been frequently used for irrigation in various concentrations $(9,15)$, literature on the effects of irrigating solutions on LPS is rare. Buttler and Crawford (9) studied the effect of three concentrations of sodium hypochlorite $(0.58 \%, 2.79 \%$ and $5.20 \%)$ on LPS and reported that none of these solutions inactivated LPS in vivo, although in vitro this had occurred. Aibel and Stevens (16) reported that $1.2 \%$ chlorhexidine led to little or no LPS inactivation, in vitro.

In spite of the less severe inflammatory infiltrate in the groups irrigated with 5\% sodium hypochlorite and $2 \%$ chlorhexidine in the present study, LPS was not totally inactivated. These results are in agreement with an in vitro study by Buck et al. (17) who reported that water, $0.12 \%$ chlorhexidine, $0.12 \%$ chlorhexidine plus $2.65 \%$ sodium hypochlorite, and $2.65 \%$ sodium hypochlorite had little or no effect on LPS when used for irrigation.

As reported by Nissan et al. (18), endotoxin is capable of penetrating dentin up to $0.5 \mathrm{~mm}$. We believe that mechanical preparation leads to the elimination of a considerable quantity of LPS in the root canal and on the dentin. However, in the present study, none of the irrigating solutions were totally effective on the endotoxin in the periapical region.

\section{RESUMO}

O objetivo deste estudo foi avaliar, histopatologicamente, o efeito do preparo biomecânico com diferentes soluções irrigadoras em dentes de cães preenchidos com LPS bacteriano após pulpectomia. Foram utilizados 120 canais radiculares de 6 cães, os quais foram preenchidos com solução de LPS após pulpectomia. As soluções irrigadoras usadas foram solução de hipoclorito de sódio a $1,2.5$ e $5 \%$ e solução de clorexidina a $2 \%$. Nenhuma irrigação foi realizada no grupo controle. Os animais foram mortos após 60 dias, e os dentes foram fixados e desmineralizados. Em seguida, cortes seriados de $6 \mu \mathrm{m}$ de espessura foram corados com hematoxilina e eosina e Tricrômico de Mallory para análise histopatológica e Brown e Brenn para verificação da contaminação bacteriana. A avaliação demonstrou que o infiltrado inflamatório foi estatisticamente menos intenso nos grupos cujos canais radiculares foram irrigados com solução de hipoclorito de sódio a $5 \%$ e de clorexidina a $2 \%$. Contudo, nenhuma das soluções irrigadoras inativou completamente os efeitos deletérios do LPS. O preparo biomecânico coadjuvado por diferentes soluções irrigadoras não inativaram completamente a endotoxina.

\section{ACKNOWLEDGMENTS}

This research was supported by FAPESP (Fundação de Amparo à Pesquisa do Estado de São Paulo, Brazil).

\section{REFERENCES}

1. Wang CY, Stashenko P. Characterization of bone-resorbing activity in human periapical lesions. J Endod 1993;19:107-111.

2. Yamasaki M, Kumazawa M, Kohsaka T, Nakamura $H$, Kameyama Y. Pulpal and periapical tissue reactions after experimental pulpal exposure in rats. J Endod 1994;20:13-17.

3. Ito H-O, Shuto T, Takada H, Koga T, Ainda Y, Hirata M, Koga T. Lipopolysaccharides from Porhyromoinas gingivalis, Prevotella intermedia and Actinobacillus actinomycetemcomitans promote osteoclastic differentiation in vitro. Archs Oral Biol 1996;41:439444.

4. McCormick JE, Weine FS, Maggio JD. Tissue pH of development periapical lesions in dogs. J Endod 1983;9:47-51.

5. Stern MH, Dreizen S, Ott TW, Levy BM. Antibody-producing cells in human periapical granulomas and cysts. J Endod 1981;7:447-452.

6. Aqrabawi J, Schilder H, Toselli P, Franzblau C. Biochemical and histochemical analysis of the enzyme arylsulfatase in human lesions of endodontic origin. J Endod 1993;19:335-338.

7. Dwyer TG, Torabinejad M. Radiographic and histologic evaluation of the effect of endotoxin on the periapical tissues of the cat. J Endod 1981;7:31-35.

8. Leonardo MR, Silva LAB, Tanomaru Filho M, Bonifácio KC, Ito IY. In vitro evaluation of the antimicrobial activity of a castor oilbased irrigant. J Endod 2001;27:717-719.

9. Buttler TK, Crawford JJ. The detoxifying effect of varying concentrations of sodium hypochlorite on endotoxins. J Endod 1982;8:59-66.

10. Berutti E, Marini R, Angeretti A. Penetration ability of different irrigants into dentinal tubules. J Endod 1997;23:725-727.

11. Heling I, Chandler NP. Antibacterial effect of irrigant combinations within dentinal tubules. Int Endod J 1998;31:8-14.

12. Silva LAB, Nelson-Filho P, Leonardo MR, Rossi MA, Pansani CA. Effect of calcium hydroxide on bacterial endotoxin in vivo. J Endod 2002;28:94-98.

13. Sundqvist G. Ecology of the root canal flora. J Endod 1992;18:427-430.

14. Assed S, Ito IY, Leonardo MR, Silva LAB, Lopatin D. Anaerobic microorganisms in root canals of human teeth with chronic apical periodontitis detected by immunofluorescence. Endod Dent Traumatol 1996;12:66-69.

15. Leonardo MR, Tanomaru Filho M, Silva LAB, Nelson-Filho P, Bonifácio $\mathrm{KC}$, Ito IY. In vivo antimicrobial activity of $2 \%$ chlorhexidine used as a root canal irrigating solution. J Endod 1999;25:167-171.

16. Aibel K, Stevens R. Effect of chlorhexidine on IL-6 induction by LPS. J Endod 1999;25:282 (abstract).

17. Buck RA, Cai J, Eleazer PD, Staat RH, Hurst HE. Detoxification of endotoxin by endodontic irrigants and calcium hydroxide. J Endod 2001;27:325-327.

18. Nissan R, Segal H, Pashley D, Stevens R, Trowbridge H. Ability of bacterial endotoxin to diffuse through human dentin. J Endod 1995;21:62-64. 